\title{
ANTIMICROBIAL SUSCEPTIBILITY PROFILES OF ESCHERICHIA COLI ISOLATES FROM DIARRHEIC DOGS IN MAIDUGURI, BORNO STATE, NIGERIA
}

\author{
Muhammad Mustapha ${ }^{1}$, Yusuf Audu', Kingsley Uwakwe Ezema², \\ Jafar Umar Abdulkadir', Jallailudeen Rabana Lawal' ${ }^{1}$, Arhyel Gana Balami \\ Lawan Adamu1, Yachilla Maryam Bukar-Kolo ${ }^{1}$ \\ ${ }^{1}$ Department of Veterinary Medicine, Faculty of Veterinary Medicine, University of \\ Maiduguri, Bama Road, P.M.B. 1069, Maiduguri, Borno State, Nigeria \\ ${ }^{2}$ Veterinary Teaching Hospital, Faculty of Veterinary Medicine, University of Maiduguri, \\ Borno State, Nigeria
}

Received 22 March 2020; Received in revised form 8 November 2020; Accepted 9 November 2020

\begin{abstract}
Diarrhea caused by multidrug-resistant Escherichia coli (E. coli) is an important and common problem in companion animals, especially dogs. Moreover, these dogs may serve as a reservoir of pathogenic strains of $E$. coli that may cause enteric and extra-intestinal infections in humans and other animals. This study was conducted to investigate the antibiotic susceptibility pattern of $E$. coli isolates from diarrheic dogs in Maiduguri Metropolis, Borno State, Nigeria. In fecal samples of 200 dogs with diarrhea, $147 \mathrm{E}$. coli strains $(73.5 \%)$ were isolated and characterized by the standard bacteriological techniques (culture, biochemical tests, and antimicrobial susceptibility testing). Out of the 147 positive isolates, 45, 50, and 52 were from Elkanemi Park, Magaram, and Sabon gari wards respectively. The isolates show 100\% resistance to chloramphenicol, cefuroxime, and ceftriaxone, $96.6 \%$ to amoxicillin, and $95.9 \%$ to gentamicin, while all $(100 \%)$ were susceptible to ciprofloxacin. All the isolates showed multiple antimicrobial resistance. The result of the current study showed that dogs in Maiduguri are important reservoirs of multidrug-resistant $E$. coli. Therefore, it is important to adopt and apply guidelines for the correct use of antimicrobials in small animal practice to reduce the emergence of multidrug resistance among E. coli in companion animals.
\end{abstract}

Key words: Escherichia coli, dogs, diarrhea, antimicrobial susceptibility

\section{INTRODUCTION}

Diarrhea in canines is one of the most common problems small animal practitioners face with today, and bacterial enteropathogens play a vital role in many of these cases (1). Clinical signs can differ among moderate, self-limiting diarrhea, and an acute, potentially fatal, diarrheal syndrome (2). Pathogenic Escherichia coli, Clostridium

Corresponding author: Dr. Muhammad Mustapha, $\mathrm{PhD}$

E-mail address: tanimuzimbos@gmail.com

Present address: Department of Veterinary Medicine, Faculty of

Veterinary Medicine, University of Maiduguri, Bama Road, P.M.B. 1069,

Maiduguri, Borno State, Nigeria

Phone: +2348035502325

Copyright: (C) 2020 Mustapha M. This is an open-access article published under the terms of the Creative Commons Attribution License which permits unrestricted use, distribution, and reproduction in any medium, provided the original author and source are credited. Competing Interests: The authors have declared that no competing interests exist.

Available Online First: 28 December 2020

Published on: 15 March 2021

https://doi.org/10.2478/macvetrev-2020-0035 perfringens, Clostridium difficile, Campylobacter spp. and Salmonella spp. are the most commonly reported canine diarrheal bacteria (2).

Escherichia coli (E. coli), a member of the family Enterobacteriaceae, is part of a normal animal and human commensal bacterial flora $(3,4)$. E. coli is strongly involved in clinical cases of dog diarrhea (3). Diarrheagenic E. coli isolate may belong to the enteroinvasive E. coli (EIEC), enterohaemorrhagic E. coli (EHEC), enteropathogenic E. coli (EPEC), entroaggregative $E$. coli (EAEC), necrotoxic E. coli (NTEC), enterotoxigenic/shiga-like toxinproducing E. coli (STEC) or diffusely adherent E. coli (DAEC) strain/pathotypes, depending on the type of virulent gene(s) being formed and the type of lesion-induced $(3,5)$.

Canine diarrhea may not be caused primarily by $E$. coli, while pathogenic $E$. coli strains have been widely incriminated in human and animal 
cases of diarrhea (6). Numerous infective (canine distemper, parvoviral enteritis, coronavirus infection, and helminthiasis) and non-infective conditions in dogs include alterations in intestinal mucosa consistency resulting in enteritis and diarrhea (7). Under these conditions, pathogenic $E$. coli is being released by the feces and may cause immune depression. E. coli strains have been documented to harbor genes that encode virulent pathogenic factors $(5,6)$. Virulence factors which are often present in pathogenic E. coli strains are used for the classification of different pathotypes (stx1, stx2, cnf1, cnf2, and eae) (3). These virulent factors were widely reported to be associated with human and animal diarrhea cases (8).

The use of antibacterial agents in dogs (fluoroquinolones, potentiated sulfonamides, penicillins, cephalosporins, chloramphenicols, tetracyclines, and aminoglycosides) in suspected cases of bacterial infection is often performed by veterinary clinicians and non-veterinarians, particularly in countries where there are no strict regulations for the use of these drugs $(7,9,10)$. This led to increased identification of antimicrobialresistant $E$. coli, both pathogenic and nonpathogenic strains, in the companion animals worldwide $(9,11)$.

E. coli develops resistance as a result of prolonged exposure to antibacterial agents, particularly when applied in subtherapeutic doses, and by acquiring antibacterial resistance genes from other commensals or transient pathogens that colonize the body or the environment $(4,12$, 13). Shedding fecal E. coli is an important source of environmental contamination by companion animals. Animals with clinical manifestations of diarrhea usually suffer from immune suppression which favors increased fecal shedding of E. coli (15). Such animals defecate frequently and uncontrollably thus spreading the bacterium (13). Moreover, pathogen presence in dog's diarrheal feces poses a serious threat to public health after zoonotic transmission. Dog owners/trainers, children, and veterinarians are at higher risk as a result of handling and close contact with these animals (16).

Isolation and identification of antimicrobialresistant diarrheagenic E. coli have been reported from dogs with or without diarrhea, and their handlers in Europe, America, Asia and North Africa $(12,13,15,17,18)$. Nevertheless, there is comparatively less knowledge in West Africa about the prevalence and antimicrobial resistance of E. coli isolates in diarrheal dogs, which was the main motive for our investigation.

\section{MATERIAL AND METHODS}

\section{Study area}

The present study was conducted in Maiduguri Metropolis, Borno State Nigeria. This area lies within the semi-arid zone of the North-Eastern part of Nigeria (19). Borno State is situated between Latitude $11^{\circ} 46^{\prime} 18^{\prime \prime} \mathrm{N}-11^{\circ} 53^{\prime} 21^{\prime \prime} \mathrm{N}$ and Longitudes $13^{\circ} 02^{\prime} 23^{\prime \prime} \mathrm{E}-13^{\circ} 14^{\prime} 19^{\prime \prime} \mathrm{E}(20,21,22)$ (Fig. 1).

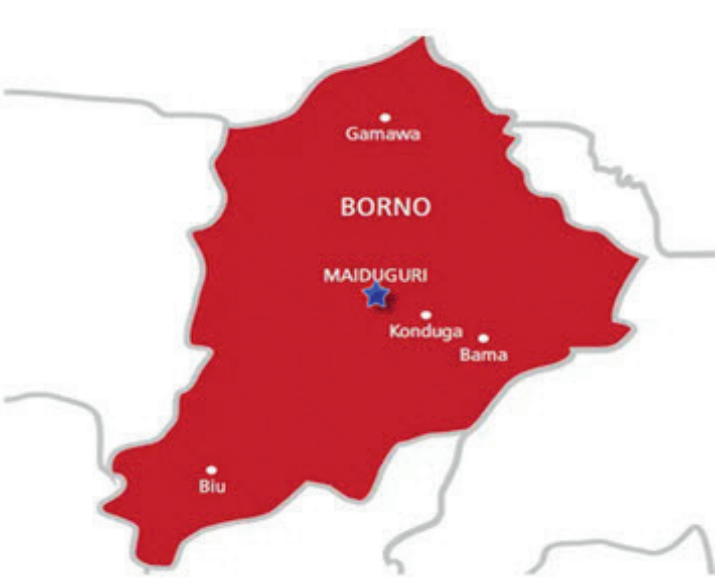

Figure 1. Map of the studied area (asterisk). Source: Google map

\section{Study population}

Rectal swab samples were randomly collected from diarrheic dogs in Magaram and Sabon layi wards, including Elkanemi Park in Maiduguri. Samples were collected from June to September 2019. Dogs were categorized based on breed, age, sex, and management system (owned or stray). Dogs from 0-12 months were considered as puppies, while above 12 months as adult dogs.

\section{Sample collection}

Two hundred rectal swab samples were collected using sterile swab sticks (Oxoid, UK). All the samples were labeled with an identification number and date of collection and immediately transported on ice-pack to the Department of Veterinary Medicine Diagnostic Research laboratory, University of Maiduguri for analysis.

\section{Bacteriological examination}

The fresh rectal swab samples were inoculated onto MacConkey agar (MCA, HiMedia, Mumbai, India) applying the quadrant streak plate method for pure colony isolation. Each plate was labeled 


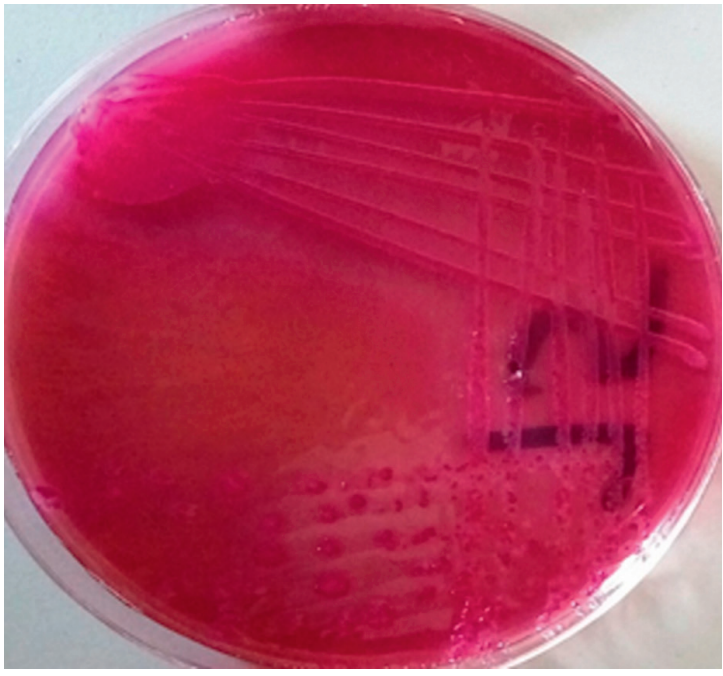

Figure 2. A typical pinkish colonies of positive isolate on MacConkey Agar

accordingly, and thereafter incubated aerobically at $37^{\circ} \mathrm{C}$ for 24 hours. The pink (lactose fermenting) colonies (Fig. 2) were selected and subcultured onto Eosin Methylene Blue agar (EMB, HiMedia, Mumbai, India) and incubated at $37^{\circ} \mathrm{C}$ for 24 hours to obtain a pure strain culture. Subcultured strains from MacConkey agar, which appeared as smooth, glossy, pinkish, with a greenish metallic sheen on EMB (Fig. 3), were presumptively considered as E. coli. These strains were further confirmed as E. coli by Gram staining, and standard biochemical tests (Indole, Methyl-Red, Voges-Proskauer, Citrate utilization, and Urease test). All confirmed isolates were streaked on a nutrient agar slant and stored at $4{ }^{\circ} \mathrm{C}$ for further use.

\section{Antimicrobial susceptibility testing}

The antibiotic susceptibility testing of the isolates was carried out using the disc diffusion method according to the Clinical and Laboratory Standards Institute (CLSI) guidelines (23). Briefly, wellisolated colonies were transferred into a test tube of brain heart infusion broth (BHI, HiMedia, Mumbai, India) and incubated for $2-5$ hours at $37{ }^{\circ} \mathrm{C}$ to obtain turbidity equivalent to $0.5 \mathrm{McFarland}$ standard. By sterile cotton swab stick, the broth culture was then

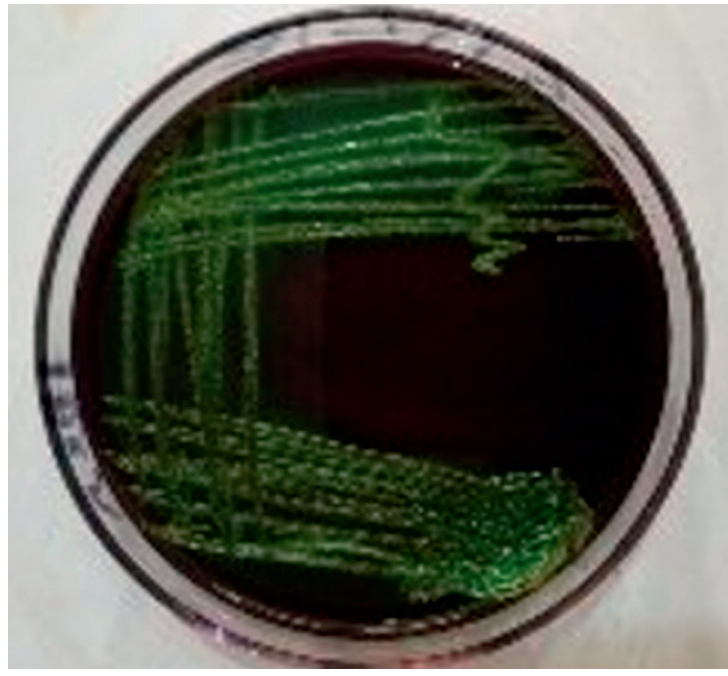

Figure 3. An intense blue-green metallic sheen colouration of E. coli on Eosin Methylene Blue (EMB) agar

evenly spread over the surface of Mueller Hinton agar plates (HiMedia, Mumbai, India). The strip with multiple antibiotics was placed on the agar and gently pressed with sterile forceps to obtain uniform close contact with the medium. The antibiotics used in the present study were: Nitrofurantoin (N, $100 \mu \mathrm{g})$, Gentamicin (GN, $10 \mu \mathrm{g}$ ), Ciprofloxacin (CIP, $10 \mu \mathrm{g}$ ), Chloramphenicol (C, $10 \mu \mathrm{g})$, Ofloxacin (OF, $10 \mu \mathrm{g})$, Cefuroxime (CF, $30 \mu \mathrm{g}$ ), Pefloxacin (PF, $10 \mu \mathrm{g}$ ), Ceftriaxone (CT, $30 \mu \mathrm{g})$, Amoxicillin (AX, $30 \mu \mathrm{g})$ and Streptomycin (ST, $30 \mu \mathrm{g}$ ) (Polytes Medical Laboratories, Enugu Nigeria). The plates were then incubated aerobically at $37{ }^{\circ} \mathrm{C}$ for 24 hours. The diameter of each zone of inhibition (in $\mathrm{mm}$ ) was measured. The interpretation of the measurement was described as sensitive (S), intermediate (I), and resistant (R), according to the CLSI manual (23).

\section{RESULTS}

Out of 200 rectal swab samples, 147 (73.5\%) were positive for $E$. coli. The highest number of positive samples were detected in Elkanemi Park (90\%), followed by Magaram (71\%) and Sabon gari (65\%) (Table 1).

Table 1. Frequency of E.coli isolates from 3 areas within Maiduguri Metropolis

\begin{tabular}{lccc}
\hline Area & No. of swab samples & No. of positive samples & Positive by region (\%) \\
\hline Magaram & 70 & 50 & 71.42 \\
Sabon gari & 80 & 52 & 65.00 \\
Elkanemi Park & 50 & 45 & 90.00 \\
Total & 200 & 147 & 73.50 \\
\hline
\end{tabular}




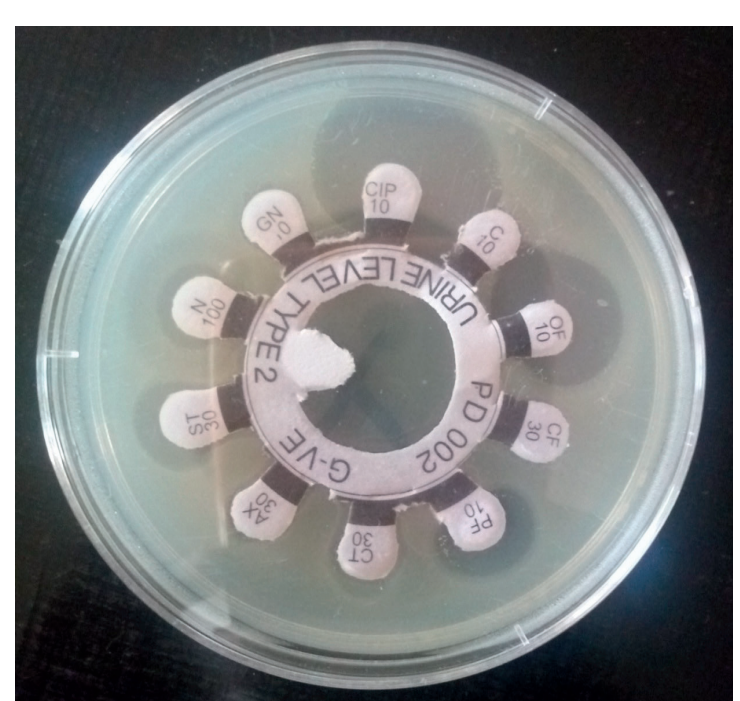

Figure 4. Antibiotic susceptibility pattern of E. coli isolates showing various zones of inhibition.
Antimicrobial susceptibility profile of the E. coli

The result of antimicrobial susceptibility tests (Table 2 and Fig. 4) have shown high resistance to Chloramphenicol (147 isolates, 100\%), Cefuroxime (147 isolates, 100\%), Ceftriaxone (147 isolates, 100\%), Amoxicillin (142 isolates, 96.6\%), Gentamicin (141 isolates, 95.9\%) and Nitrofurantoin (114 isolates, 77.6\%), while the isolates were highly susceptible to Ciprofloxacin (147 isolates, 100\%). Multiple antibiotic resistance was detected in all E. coli isolates, as shown in Table 3 .

\section{DISCUSSION}

The overall isolation rate of $E$. coli from diarrheic dogs in this study was very high (73.5\%), most likely as a consequence of the interaction between the pets and stray dogs which increased

Table 2. Antibiotic susceptibility pattern of $E$. coli isolated from dogs $(\mathrm{n}=147)$

\begin{tabular}{lccc}
\hline Antibiotics & Resistant isolates (\%) & Intermediate t isolates (\%) & Susceptible isolates (\%) \\
\hline Nitrofurantoin (N) & $114(77.6)$ & $21(14.3)$ & $12(8.2)$ \\
Gentamicin (GN) & $141(95.9)$ & $6(4.1)$ & 0.0 \\
Ciprofloxacin (CIP) & 0.0 & 0.0 & $147(100.0)$ \\
Chloramphenicol (C) & $147(100.0)$ & 0.0 & 0.0 \\
Ofloxacin (OF) & $5(3.4)$ & $83(56.5)$ & $59(40.1)$ \\
Cefuroxime (CF) & $147(100.0)$ & 0.0 & 0.0 \\
Pefloxacin (PF) & $5(3.4)$ & 0.0 & $64(43.5)$ \\
Ceftriaxone (CT) & $147(100.0)$ & $5(3.5)$ & 0.0 \\
Amoxicillin (AX) & $142(96.6)$ & $59(40.1)$ & 0.0 \\
Streptomycin (ST) & $54(36.7)$ & & $34(23.1)$ \\
\hline
\end{tabular}

Table 3. Multidrug resistance profile of $E$. coli isolates in dogs in this study

\begin{tabular}{ccc}
\hline Number of drugs & Number of isolates & Frequency (\%) \\
\hline $\mathbf{0}$ & 0 & 0.0 \\
$\mathbf{1}$ & 9 & 6.1 \\
$\mathbf{2}$ & 12 & 8.2 \\
$\mathbf{3}$ & 10 & 6.8 \\
$\mathbf{4}$ & 18 & 12.2 \\
$\geq \mathbf{5}$ & 34 & 23.1 \\
\hline
\end{tabular}


Antimicrobial susceptibility of $E$. coli isolates from diarrheic dogs

the potential for pathogenic E. coli transmission and spreading among the investigated animals. These findings concurred with the study carried out by Puno-Sarmiento et al. (3).

This high prevalence of E. coli $(73.5 \%)$ in both categories of diarrheic dogs (puppies and adults) sampled from different areas within Maiduguri metropolis (Magaram, Sabon layi and Elkanemi Park) is in agreement with the results of Yousif et al. (24), who reported a high prevalence of E. coli $(83 \%)$ in adult dogs and puppies, and with the results of Hassan (27) reporting high prevalence in both diarrheic categories $(68.75 \%)$ and low prevalence rate $(7.95 \%)$ in non-diarrheic categories. The significance of $E$. coli pathogenicity has been confirmed with the findings of Wang et al. (25) reporting that all dogs developed acute watery or mucous diarrhea on the second day of infection, and a study from Brazil where out of 154 stool samples tested, 37 (24\%) were positive for E. coli strains, harboring at least one virulence gene detected in PCR analysis (26).

In the current research, the $E$. coli prevalence rate recorded in Elkanemi Park was higher than that recorded in Magaram and Sabon Gari. This may be due to the feeding habits of dogs in this area, because they are typically fed food leftovers found in dumpy areas across the ward. Foodborne transmission is the most important common means of infection (28), especially in places contaminated by feces which is containing E. coli (14).

The antimicrobial susceptibility pattern of E. coli isolates recorded in the present study established a high level of resistance to Chloramphenicol, Cefuroxime, Ceftriaxone, Amoxicillin, and Gentamicin. The E. coli isolates were highly susceptible to Ciprofloxacin, and this could probably be due to the infrequent use of this drug in the studied area. This is in agreement with Aslani et al. (29), who reported that only a few isolates were resistant to ciprofloxacin, and the results of Grave et al. (30), where the high sensitivity was shown only to ciprofloxacin among the used antimicrobials. Antimicrobial resistance in bacteria is a phenomenon that has been in constant evolution since the introduction of antibiotics. Several factors are known to promote bacterial resistance, including failure to follow the treatment regimen, prophylactic use of antibiotics, and the use of antibiotics as growth promoters. Fluoroquinolones are newer drugs that are relatively expensive, and therefore less available for use and potential abuse in the study areas. Therefore, the infrequent use of this drug in these areas is probably the main reason for high susceptibility to Ciprofloxacin of isolated E. coli strains.

However, our results are incompatible with the findings by Younis et al. (18), who reported that $E$. coli isolates were sensitive only to amikacin. These reports and the findings of the present study indicate different resistance patterns of $E$. coli.

Multidrug resistance is a condition in which bacteria are resistant to a specific drug in three or more antimicrobial classes $(30,31)$. Multidrug resistance to different antibiotics recorded in this study corresponds with the findings of Puno-Sarmiento et al. (3), who reported multiresistant strains in most diarrheic $E$. coli strains to both the frequently and less-frequently used antimicrobials.

Most dog owners seek out for the aid of a veterinarian only when their pets display overt disease signs, which is especially common in developing countries where most dog owners rarely carry out preventive programs. Normally, in rural and suburban areas the level of compliance may be even more reduced. However, a considerable number of dog owners are increasingly aware of the risks and potential costs related to the nonadoption of preventive measures directed to avoiding exposure to certain pathogens, such as E. coli. Thus, it is fundamental that veterinarians guide dog owners towards the establishment of long-term preventive programs against infectious diseases including those caused by E. coli.

\section{CONCLUSION}

The results of the present study confirmed the presence of $E$. coli in $73.50 \%$ dogs with diarrhea in Maiduguri area. The highest number of positive samples was obtained in Elkanemi Park $(90.00 \%)$, compared to Magaram (71.42\%) and Sabon gari ward (65.00\%). All isolates shown antimicrobial resistance to Chloramphenicol, Cefuroxime, Ceftriaxone, Amoxicillin, and Gentamicin. However, Ciprofloxacin has shown $100 \%$ antibacterial efficiency against obtained $E$. coli isolates, which indicates to be a first choice of antimicrobial for the treatment of dogs with diarrhea in the studied areas. Furthermore, it is important to adopt and apply guidelines for the correct use of antimicrobials in small animal practice to reduce the emergence of multidrug resistance among E. coli in companion animals. 


\section{CONFLICT OF INTEREST}

The authors declared that they have no potential conflict of interest with respect to the authorship and/or publication of this article.

\section{ACKNOWLEDGEMENTS}

We thank Mal. Isa Adamu Gulani for expert technical assistance.

\section{AUTHORS' CONTRIBUTIONS}

MM, YA, YMBK and LA planned and designed the experiments. MM carried out the study and KUE, JUA, JRL, and AGB provided technical support. MM and LA carried out statistical analysis. All authors read and approved the manuscript.

\section{REFERENCES}

1. Greene, C.E. (1998). Infectious diseases of the dog and cat. In: C.E. Greene (Ed.), Enteric bacterial infections. 2nd ed. (243-245). Toronto, Ontario: WB Saunders Company.

2. Cave, N.J., Marks, S.L., Kass, P.H., Melli, A.C., Brophy, M.A. (2002). Evaluation of a routine diagnostic fecal panel in dogs with diarrhea. J Am Vet Med Assoc. 221(1): 52-59.

https://doi.org/10.2460/javma.2002.221.52 PMid:12420824

3. Puno-Sarmiento, J., Medeiros, L., Chiconi, C., Martins, F., Pelayo, J., Rocha, S., Blanco, J., et al. (2013). Detection of diarrheagenic Escherichia coli strains isolated from dogs and cats in Brazil. Vet Microbiol. 166(3-4): 676-680.

https://doi.org/10.1016/j.vetmic.2013.07.007 PMid:23932311

4. Tajbakhsh, E., Ahmadi, P., Abedpour-Dehkordi, E., Arbab-Soleimani, N., Khamesipour, F. (2016). Biofilm formation, antimicrobial susceptibility, serogroups, and virulence genes of uropathogenic E. coli isolated from clinical samples in Iran. Antimicrob Resist Infect Control. 5, 11. https://doi.org/10.1186/s13756-016-0109-4 PMid:27042294 PMCid:PMC4818419

5. Bien, J., Sokolova, O., Bozko, P. (2012). Role of uropathogenic Escherichia coli virulence factors in development of urinary tract infection and kidney damage. Int J Nephrol. 2021, 681473. https://doi.org/10.1155/2012/681473 PMid:22506110 PMCid:PMC3312279
6. Shahrani, M., Dehkordi, F.S., Momtaz, H. (2014). Characterization of Escherichia coli virulence genes, pathotypes and antibiotic resistance properties in diarrheic calves in Iran. Biol Res. 47(1): 28.

https://doi.org/10.1186/0717-6287-47-28 PMid:25052999 PMCid:PMC4105491

7. Torkan, S., Khamesipour, F., Anyanwu, M.U. (2015). Detection of virulence and antibacterial resistance genes in Salmonella isolates from diarrhoeic dogs in Iran. Revue Méd Vét. 166(7-8): 221-228.

8. Kavitha, K., Prabhakar, K., Rajendran, S., Uma, B., Sarayu, Y.L. (2010). Isolation of necrotoxigenic Escherichia coli from pediatric patients with acute diarrhea. J Med Microbiol. 59(Pt 4): 503-504. https://doi.org/10.1099/jmm.0.015016-0 PMid:20075117

9. Guardabassi, L., Schwarz, S., Lloyd, D.H. (2004). Pet animals as reservoirs of antimicrobial-resistant bacteria. J Antimicrob Chemother. 54(2): 321-332. https://doi.org/10.1093/jac/dkh332 PMid:15254022

10. Abatcha, M.G., Zunita, Z., Gurmeet, D.K., Thong, K.L. (2014). Occurrence of antibiotic resistant Salmonella isolated from dogs in Klang Valley, Malaysia. MJM. 10(3): 219-224. https://doi.org/10.21161/mjm.58213

11. Ewers, C., Bethe, A., Semmler, T., Guenther, S., Wieller, L.H. (2012). Extended-spectrum $\beta$-lactamaseproducing and AmpC-producing Escherichia coli from livestock and companion animals, and their putative impact on public health: a global perspective. Clin Microbiol Infect. 18(7): 646-655.

https://doi.org/10.1111/j.1469-0691.2012.03850.x PMid:22519858

12. Shaheen, B.W., Nayak, R., Foley, S.L., Kweon, O., Deck, J., Park, M., Rafii, F., Boothe, D.M. (2011). Molecular characterization of resistance to extendedspectrum cephalosporins in clinical Escherichia coli isolates from companion animals in the United States. Antimicrob Agents Chemother. 55(12): 5666-5675. https://doi.org/10.1128/AAC.00656-11 PMid:21947397 PMCid:PMC3232758

13. Torkan, S., Bahadoranian, M.A., Khamesipourc, F., Anyanwu, M.U. (2016). Detection of virulence and antimicrobial resistance genes in Escherichia coli isolates from diarrhoiec dogs in Iran. Arch Med Vet. 48(2): 181-190.

https://doi.org/10.4067/S0301-732X2016000200008

14. Morato, E.P., Leomil, L., Beutin, L., Krause, G., Moura, R.A., Pestana de Castro, A.F. (2009). Domestic cats constitute a natural reservoir of human enteropathogenic Escherichia coli types. Zoonoses Pub Health. 56(5): 229-237. https://doi.org/10.1111/j.1863-2378.2008.01190.x PMid:19068073 
Antimicrobial susceptibility of $E$. coli isolates from diarrheic dogs

15. Pereira de Almeida, P.M., Rodrigues Arais, L. Costa Andrade, J.R., Rondon Barreto Prado, E.H., Irino, K., Figueiredo Cerqueira, A.M. (2012). Characterization of atypical enteropathogenic Escherichia coli (aEPEC) isolated from dogs. Vet Microbiol. 158(3-4): 420-424.

https://doi.org/10.1016/j.vetmic.2012.02.021 PMid:22421111

16. Paula, C.J.S., Marin, J.M. (2009). Multidrugresistant Shiga toxin-producing Escherichia coli in dogs with diarrhea. Arq Bras Med Vet Zootec. 61(2): 511-514. https://doi.org/10.1590/S0102-09352009000200032

17. Rzewuska, M., Czopowicz, M., Kizerwetter-Świda, M., Chrobak, D., Błaszczak, B., Binek, M. (2015). Multidrug resistance in Escherichia coli strains isolated from infections in dogs and cats in Poland (2007-2013). Scientific World J. 2015, 408205.

https://doi.org/10.1155/2015/408205

PMid:25667937 PMCid:PMC4312638

18. Younis, K., Baddour, M., Ibrahim, M.S. (2015). Detection of diarrheagenic Escherichia coli in pet animals and its antibiotic resistance in Alexandria Governorate. AJVS. 45(1): 113-118. https://doi.org/10.5455/ajvs.181517

19. Abdulrahman, F.I., Akan, J.C., Chellube, Z.M., Waziri, M. (2012). Level of heavy metals in human hair and nail samples from Maiduguri Metropolis, Borno State, Nigeria. World Environment 2(4): 81-89. https://doi.org/10.5923/j.env.20120204.05

20. Google Earth (2012). Maiduguri Google Earth 3D map. Available from: www.maplandia.com

21. World Gazetteer (2007). Free Encyclopedia. [Internet]. Retrieved 2007-04-06.

en.wikipedia.org/wiki/Borno_State

22. Waziri, M. (2009). The geography of Borno: An overview. In: M. Waziri, A. Kagu, and K. M. Abubakar (Eds.), Issues in the Geography of Borno State World Gazetteer (pp. 6-8). Free Encyclopedia. Retrieved 2007-04-06.

23. Clinical and Laboratory Standards Institute (2012). Methods for dilution antimicrobial susceptibility tests for bacteria that grow aerobically. [Internet]. Approved Standard-Ninth Edition. CLSI, Wayne, PA, USA. 32(2): M07-A9.

https://www.medicaldesignandoutsourcing.com/clsi-publishes-2012-antimicrobial-susceptibility-testing-standards/
24. Yousif, A.A., Mustafa, S.H., Mohammad, J.A. (2016). Clinical and molecular study of E. coli O157:H7 isolated from diarrheic and non-diarrheic dogs. MRVSA. 5(2): 1-10.

25. Wang, J.Y., Wang, S.S., Yin, P.Z. (2006). Haemolyticuraemic syndrome caused by a non-O157: H7 Escherichia coli strain in experimentally inoculated dogs. J Med Microbiol. 55, 23-29.

https://doi.org/10.1099/jmm.0.46239-0

PMid:16388026

26. Coura, F.M., Diniz, A.N., Oliveira Junior, C.A., Lage, A.P., Faria Lobato, F.C., Heinemann, M.B., Silveira Silva, R.O. (2018). Detection of virulence genes and the phylogenetic groups of Escherichia coli isolated from dogs in Brazil. Ciência Rural 48(2): e20170478.

https://doi.org/10.1590/0103-8478cr20170478

27. Hasan, M.S., Yousif, A., Alwan, M.J. (2016). Detection of virulent genes in E. coli O157:H7 isolated from puppies and adult dogs by polymerase chain reaction. Res J Vet Pract 4(1): 1-6. https://doi.org/10.14737/journal.rjvp/2016/4.1.1.6

28. Chandran, A., Mazumder, A. (2013). Prevalence of diarrhea-associated virulence genes and genetic diversity in Escherichia coli isolates from fecal material of various animal hosts. Appl Environ Microbiol. 79(23): 7371-7380.

https://doi.org/10.1128/AEM.02653-13

PMid:24056456 PMCid:PMC3837721

29. Aslani, M.M., Salmanzadeh-Ahrahbi, S., Ahlikani, Y.M., Jafari, F., Zali, R.M., Mani, M. (2008). Molecular detection and antimicrobial resistance of diarrheagenic Esherichia coli isolated from diarrheal cases. Saudi Med J. 29(3): 388-392.

30. Grave, K., Tanem, H. (1999). Compliance with short-term oral antibacterial drug treatment in dogs. J Small Anim Pract. 40(4): 158-162. https://doi.org/10.1111/j.1748-5827.1999.tb03781.x PMid:10340244

31. Ben Said, L., Jouini, A., Alonso, C.A., Klibi, N., Dziri, R., Boudabous, A., Ben Slama, K., Torres, C. (2016). Characteristics of extended-spectrum $\beta$-lactamase (ESBL)- and $\mathrm{pAmpC}$ beta-lactamaseproducing Enterobacteriaceae of water samples in Tunisia. Sci Total Environ. 550, 1103-1109. https://doi.org/10.1016/j.scitotenv.2016.01.042 PMid:26871556 